\title{
Respiratory viruses: Things happened as expected. And now what?
}

The unexpected emergence of a new virus, in this case, severe acute respiratory syndrome coronavirus 2 (SARS-CoV-2), responsible for the current COVID-19 pandemic, reshapes the epidemiological aspects of other diseases. How can this experience help to find answers to public health problems that have been unresolved for years?

Bronchiolitis predominantly affects young infants and is the leading cause of seasonal hospitalization of infants in Argentina and nearly worldwide. Its main causative agent is respiratory syncytial virus (RSV), a virus that affects all age groups. No safe vaccine has been yet developed for the pediatric population. New vaccines are being investigated for pregnant women and older adults, which may reduce the risk for transmission to children, who develop more severe complications.

Given that they share similar mechanisms of transmission, it was expected that the actions taken to fight the COVID-19 pandemic, especially social isolation, social distancing, and hygiene measures, would also have an impact on the transmission of RSV and other respiratory viruses. But we should be careful with this prognosis because there are yet no complete statistical data for 2020 and we do not know what happened with children in the more vulnerable populations living in overcrowding conditions, without access to drinking water and with difficulties to access health care services.

This issue of Archivos Argentinos de Pediatría includes an article by Lución et al. about the impact of COVID-19 on the circulation of respiratory viruses in a children's hospital. ${ }^{1}$ This study observed a $73 \%$ reduction in the rates of hospitalization due to bronchiolitis and nonCOVID-19 pneumonia compared to 2019 and 2020, which is consistent with national and international data. ${ }^{2}$ A marked reduction was also observed in the detection of other respiratory viruses, and no RSV case was reported, which had been the most common agent $(71.2 \%)$ in the control year.

At a national level, bronchiolitis cases in children younger than 2 years decreased considerably. In 2019, and consistent with the prior 7 years, there were 227685 cases; whereas there were 36230 cases in 2020 and 80476 cases in 2021, until epidemiological week 42 . $^{3}$
In national respiratory virus surveillance studies conducted in 2021, up to epidemiological week 42, almost 3300000 samples tested for SARS-COV-2 were positive. Only 30000 samples across all age groups were tested for other respiratory viruses. Among positive samples, 99\% corresponded to SARS-COV-2. After the marked reduction in other respiratory viruses (RSV, influenza, parainfluenza, adenovirus) observed in 2020, they have been detected again in 2021, especially RSV in children, in accordance with the usual seasonal pattern between epidemiological weeks 11 and $34 .^{3}$ This is consistent with the progressive lessening of lockdown policies, however, far from reaching the levels befores the pandemic.

What will the characteristics of bronchiolitis be in the next months? Some variations are being observed in the presentation of respiratory viruses in different regions of the world, such as the reemergence of RSV infections outside its usual season or an increase in the number of hospitalizations among older children with severe, "non-bronchiolitis" respiratory conditions caused by RSV., Such older children without prior contact with the virus enlarge the susceptible population.

It is evident that the meassures taken to restrict COVID-19 circulation have also managed to reduce the circulation of other respiratory viruses. Studies performed using mathematical models that account for an increase in susceptible populations conclude that, once these non-pharmacological measures are removed, major RSV and influenza outbreaks will most likely occur. ${ }^{6}$

There is also a concerning possibility about the reemergence of vaccine-preventable diseases, such as measles, because turnout to vaccination centers has shown a reduction of up to $50 \%$.

This is the time to consider different aspects of noncommunicable and communicable diseases, their distinct characteristics, the possibility of them becoming epidemic, pandemic or endemic, and to analyze how measures taken to contain some diseases may impact others.

In this setting, the term "syndemic," coined by the physician and anthropologist Merrill Singer in the 1990s, acquires a current meaning due to the present pandemic. ${ }^{7}$ To call a spade a spade helps to define them.

An epidemic involves a susceptible 
population, a causative agent, and its modes of transmission. However, the concept of syndemic is much broader. It describes a synergy among different epidemics and their biological interaction, which, in turn, has an effect on population groups with unequal social, financial, and environmental conditions. This calls for providing different health policies to obtain successful results in relation to prevention or mitigation.

Two or more diseases or conditions interact causing a greater harm than the sum of them. In the case of COVID-19, it involves an infectious disease, the host's age, and a group of noncommunicable diseases that, in turn, unfold in different geographic regions, different populations with varying mobility and density, and health care systems with different levels of development. Outcomes may be markedly asymmetric in terms of morbidity and mortality.

Year after year, we witness how RSV affects the health of young children. The analysis of RSV behavior during the COVID-19 pandemic should provide innovative, probably more effective measures than the so far unsuccessful search for specific treatments. It all points towards prevention, especially if we consider that more than $50 \%$ of children in Argentina live below the poverty line. ${ }^{8-10}$

As detailed by Richard Horton in his comment published in The Lancet, approaching epidemics as syndemics "invites a larger vision, one encompassing education, employment, housing, food, and environment" ${ }^{11}$ In the specific case of bronchiolitis, in addition to all those conditions, we should mention ensuring a timely access to the health care system.

\section{Susana Rodríguez (D) Assistant Editor}

http: / / dx.doi.org/ 10.5546/ aap.2022.eng.78
To cite: Rodríguez MS. Respiratory viruses: Things happened as expected. And now what? Arch Argent Pediatr 2022;120(2):78-79.

\section{REFERENCES}

1. Lución MF, Juárez MV, Pejito MN, Orqueda AS, et al. Impacto del COVID-19 en la circulación de virus respiratorios en un hospital pediátrico: una ausencia esperada. Arch Argent Pediatr 2022; 120(2):99-105.

2. Ferrero F, Ossorio MF. Is there a place for bronchiolitis in the COVID-19 era? Lack of hospitalizations due to common respiratory viruses during the 2020 winter. Pediatr Pulmonol. 2021; 56(7):2372-3.

3. Argentina. Ministerio de Salud de la Nación. Boletín Integrado de Vigilancia semanal N572. SE 42/2021. [Accessed on: December $\left.2^{\text {nd }}, 2021\right]$. Available at: https: / / bancos.salud.gob.ar/recurso/boletin-integrado-devigilancia-n572-se-422021

4. Agha R, Avner JR. Delayed seasonal RSV surge observed during the COVID-19 pandemic. Pediatrics. 2021; 148(3):e2021052089.

5. Hussain F, Kotecha S, Edwards MO. RSV bronchiolitis season 2021 has arrived, so be prepared! Arch Dis Child. 2021; 106(12):e51.

6. Baker RE, Park SW, Yang W, Vecchi GA, et al. The impact of COVID-19 nonpharmaceutical interventions on the future dynamics of endemic infections. Proc Natl Acad Sci U S A. 2020; 117(48):30547-53.

7. Singer M, Bulled N, Ostrach B, Mendenhall E. Syndemics and the biosocial conception of health. Lancet. 2017; 389(10072):941-50.

8. Rodríguez MS. La bronquiolitis en el año del COVID-19. Arch Argent Pediatr. 2020; 118(3):222-3.

9. Argentina. Instituto Nacional de Estadísticas y Censos. Condiciones de vida. Vol.4, $\mathrm{n}^{\circ} 4$. Incidencia de la pobreza y la indigencia en 31 aglomerados urbanos. Segundo semestre de 2019. [Accessed on: December $2^{\text {nd }}, 2021$ ]. Available at: https: / / www.indec.gob.ar/uploads/informesdeprensa / eph_pobreza_02_195EFE752E31.pdf

10. UNICEF Argentina. La pobreza y la desigualdad de niñas, niños y adolescentes en la Argentina. Efectos del COVID-19. Buenos Aires; UNICEF: 2020. [Accessed on: December $2^{\text {nd }}, 2021$ ]. Available at: https: / / www.unicef.org/argentina / media / 8096/ file / COVID-19:\% 20La\% 20pobreza $\% 20$ y $\% 201$ a $\% 20$ desigualdad $\% 20 \mathrm{de} \% 20 \mathrm{ni} \% \mathrm{C} 3 \% \mathrm{~B} 1$ as,$\% 20$ ni $\%$ C $3 \%$ B1os $\% 20$ y $\% 20$ adolescentes $\% 20$ en $\% 201 \mathrm{a} \% 20$ Argentina..pdf

11. Horton R. Offline: COVID-19 is not a pandemic. Lancet. 2020; 396(10255):874. 